\title{
Agrobacterium tumefaciens-mediated transformation of common bean (Phaseolus vulgaris) var. Brunca
}

Laura Yesenia Solís-Ramos ${ }^{1 *}$, Julio César Ortiz-Pavón ${ }^{1}$, Antonio Andrade-Torres ${ }^{2}$, Romano Porras-Murillo ${ }^{1}$, Arturo Brenes Angulo ${ }^{3}$ \& Enrique Castaño de la Serna ${ }^{4}$

1. Biotecnología de Plantas, Escuela de Biología, Universidad de Costa Rica, Sede Rodrigo Facio, San Pedro, San José, Costa Rica; laura.solisramos@ucr.ac.cr; jcesar_pavon@hotmail.com; rpmurillo@gmail.com

2. Biotecnología y Ecología de Organismos Simbióticos, INBIOTECA (Instituto de Biotecnología y Ecología Aplicada), Universidad Veracruzana, Veracruz, México. CA-UVER-173; aandrade@uv.mx

3. Laboratorio de Biotecnología de Plantas, Centro de Investigaciones Agronómicas (CIA), Universidad de Costa Rica, Sede Rodrigo Facio, San Pedro, San José, Costa Rica; arturo.brenes@ucr.ac.cr

4. Unidad de Bioquímica y Biología Molecular de Plantas, CICY (Centro de Investigación Científica de Yucatán), Mérida, Yucatán, México; enriquec@cicy.mx

* Correspondence

Received 11-X-2017. Corrected 18-XII-2018. Accepted 17-I-2019.

\begin{abstract}
Common bean is a crop recalcitrant to in vitro regeneration and therefore it lacks an efficient transformation protocol that can be reproduced using A. tumefaciens. The main goal of this study was to establish a protocol for A. tumefaciens mediated transformation of Phaseolus vulgaris var. Brunca by marker genes (gusA and $n p t I I)$ together with the gene for trehalose-6-phosphate synthase from Saccharomyces cerevisiae (TPS1) used in other species to increase tolerance to abiotic stress. The $\beta$-glucuronidase activity was detected in 45 $\%$ of the LBA4404 ElectroMAX ${ }^{\circledR}$ pCAMBIA1301 infected explants. Transformed explants regenerated new shoots after four to five months period in a kanamycin rich media. Surviving plants were evaluated by PCR and presented an $0.5 \%$ efficiency of transformation. The established protocol for genetic transformation of common bean has two additional advantages with respect to previous reports: (1) it allows for obtaining transformed regenerants and (2) the genetic transformation was stable for the selective gene.
\end{abstract}

Key words: common bean; recalcitrant species; genetic transformation; A. tumefaciens; gusA activit; nptII.

Solís-Ramos, L. Y., Ortiz-Pavón, J. C., Andrade-Torres, A., Porras-Murillo, R., Brenes Angulo, A., \& Castaño de la Serna, E. (2019). Agrobacterium tumefaciens-mediated transformation of common bean (Phaseolus vulgaris) var. Brunca. Revista de Biología Tropical, 67(2) Suplemento, S83-S94.

Phaseolus vulgaris is cultivated and consumed primarily in Latin America, Africa and Asia (Gepts et al., 2008). Several attempts have been made to transform the species to obtain traits that otherwise cannot be achieved by traditional crosses (Amugune, Anyango, \& Mukiama, 2011). Some genetic manipulations have been carried out with biolistic but at low efficiencies (0.03-0.9 \%) (Russell, Wallace,
Bathe, Martinell, \& McCabe, 1993; Aragão et al., 1996; Vianna et al., 2004).

Transgenic plants of $P$. vulgaris have been obtained with resistance to bean golden mosaic virus (BGMV) and with increased tolerance to herbicide ammonium gluphosinate Imazapyt by the biolistic approach (Aragão, Vianna, Albino, \& Rech, 2002; Rech, Vianna, \& Aragão, 2008; Aragão, Nogueira, Tinoco, \& Faria, 2013). 
Transformed plants with the mutant gene associated to the Rep protein have shown a partial resistance to the BGMV and this trait has been then transferred to four commercial cultivars by traditional crosses (Faria et al., 2006). Furthermore a BGMV (EMBRAPA 5.1) was resistant line made by transforming with a genetic silence system against the viral gene rep (AC1) (Bonfim, Faria, Nogueira, Mendes, \& Aragão, 2007; Aragão \& Faria, 2009; Aragão et al., 2013). However, such transformation has a low efficiency and higher cost compared to the use of Agrobacterium-mediated transformation (Amugune et al., 2011).

There have been several efforts to conduct genetic transformation via A. tumefaciens (Franklin, Trieu, Cassidy, Dixon, \& Nelson, 1993; Zhang, Coyne, \& Mitra, 1997), with the efficiency of 2.8- to $28.6 \%$ (Espinosa-Huerta, Quintero-Jiménez, Cabrera-Becerra, \& MoraAvilés, 2013; Collado et al., 2015). Regeneration of plants from transformed explants is difficult in genetic transformation protocols, and for recalcitrant species like common bean is one of the unsolved aspects (Liu, Park, Kanno, \& Kameya, 2005; Amugune et al., 2011; Collado et al., 2015). Recently the green nodular compact calli were used as explants to obtain transformed plants, based on the indirect organogenesis regeneration pathway (Collado et al., 2015, 2016).

An efficient system for transformation remains elusive for Phaseolus vulgaris. Main goal of this study was to develop a transformation protocol for Phaseolus vulgaris var. Brunca via Agrobacterium tumefaciens considering several factors like bacterial concentration, incubation of the pre-culture and co-cultivation, antibiotics used and lethal concentrations of selective agents.

\section{MATERIAL AND METHODS}

Plant materials: Experiments were performed from 2012 to 2015 using mature common bean seeds var. Brunca (its color black) donated by the Fabio Baudrit Moreno Agricultural Experimental Station [Estación
Experimental Agrícola Fabio Baudrit Moreno (EEAFBM)] of the University of Costa Rica, located in La Garita de Alajuela, Costa Rica.

Seeds were firstly surface-sterilized according to Solís-Ramos et al. (2015). Embryonic axes (EA) were extracted with cutters, tweezers and stereoscopic microscope. The samples were surface-sterilized a second time with a solution of $0.1 \%$ of bleach (commercial sodium hypochlorite) for $10 \mathrm{~min}$ and subsequently washed three times with sterile distilled water. Finally, EA were placed in the regeneration medium (RM) in petri dishes. For experiments whose pre-cultivation periods were considered, embryos were extracted at the moment of bacterial immersion by removing cotyledons and radicles.

Regeneration medium: Murashige \& Skoog (1962) (MS) medium added with 1 $\mathrm{mg} / \mathrm{L}$ BAP, $30 \mathrm{~g} / \mathrm{L}$ sucrose, and $6 \mathrm{~g} / \mathrm{L}$ agar was used (Solís-Ramos et al., 2015). The pH was adjusted to 5.7 prior to autoclave sterilization $\left(120{ }^{\circ} \mathrm{C}, 15 \mathrm{~kg} / \mathrm{cm}^{2}\right.$, for $\left.20 \mathrm{~min}\right)$. The cultures were incubated at $26 \pm 1{ }^{\circ} \mathrm{C}$ with a photoperiod of $12 \mathrm{~h} \mathrm{light}\left(30 \mu \mathrm{mol} / \mathrm{m}^{2} \mathrm{~s}\right)$ and $12 \mathrm{~h}$ darkness.

Activation of bacterial strains: Agrobacterium LBA4404-ElectroMAX ${ }^{\circledR}$ cells (transformed with bifunctional BinRD29A or pCAMBIA1301 plasmids) were cultured in 25 $\mathrm{mL}$ of liquid Luria-Bertani (LB) medium (10 $\mathrm{g} / \mathrm{L}$ triptone, $5 \mathrm{~g} / \mathrm{L} \mathrm{NaCl}, 5 \mathrm{~g} / \mathrm{L}$ yeast extract) containing the appropriate antibiotics and allowed to grow for $48 \mathrm{~h}$ at $28^{\circ} \mathrm{C}$ with $160 \mathrm{rpm}$ agitation according to Solís-Ramos, GonzálezEstrada, Nahuath-Dzib, Zapata-Rodriguez, \& Castaño (2009). Subsequently, $200 \mu \mathrm{l}$ of the bacterial suspension were inoculated in $25 \mathrm{~mL}$ of fresh LB medium containing the required antibiotics. The culture was allowed to grow for $24 \mathrm{~h}$ at $28{ }^{\circ} \mathrm{C}$ and $160 \mathrm{rpm}$ agitation. Then, $25 \mathrm{~mL}$ of LB and $100 \mu \mathrm{M}$ of acetosyringone (4'-hydroxy-3',5'-dimethoxyacetophenone) were added to the $24-\mathrm{h}$ culture which was incubated for $4 \mathrm{hr}$ at $28{ }^{\circ} \mathrm{C}$ and $160 \mathrm{rpm}$ agitation. The bacterial suspension was centrifuged at $5000 \mathrm{rpm}$ during $5 \mathrm{~min}$ at room temperature 
and resuspended in $20 \mathrm{~mL}$ of MS liquid media containing $1 \mathrm{mg} / \mathrm{L}$ BAP and $100 \mu \mathrm{M}$ of acetosyringone until it reached 0.5 or 0.8 OD600nm depending on the treatment. The inocultion was performed by immersing the explants in the bacterial suspension for 15 min under constant agitation $(900 \mathrm{rpm})$, and bacterial suspension excess was eliminated with sterile towel paper. The co-cultivation was performed in Petri dishes with regeneration medium under complete darkness at $25 \pm 1{ }^{\circ} \mathrm{C}$ and co-cultivation time depended on the treatments of each experiment.

Bacteria elimination after co-cultivation: The Agrobacterium elimination was performed after the co-cultivation in pre-cultivated or non-pre-cultivated explants. Explants were shaken at $90 \mathrm{rpm}$ for $15 \mathrm{~min}$ in the bacterial suspension and then co-cultivated for four days. After co-cultivation, explants were washed three times with sterile distilled water for 5-10 min (manual agitation) with subsequent vacuum infiltration at $1.25 \mathrm{plg} \mathrm{Hg}$ during 30-40 min with solutions containing timemtin, cefotaxime or a mixture of both. The following treatments were evaluated: (T1) non-infected EA on antibiotic-free RM, (T2) co-cultivated EA on antibiotic-free RM, (T3) cocultivated EA on RM containing $500 \mathrm{mg} / \mathrm{L}$ timentin and $500 \mathrm{mg} / \mathrm{L}$ cefotaxime, (T4) co-cultivated EA on RM containing $500 \mathrm{mg} / \mathrm{L}$ timentin, and (T5) co-cultivated EA on RM containing $750 \mathrm{mg} / \mathrm{L}$ timentin.

EAs water excess was adsorbed with sterile paper towels before they were cultured in the RM supplemented with the selected treatment. Then, they were cultured under the conditions described previously. Twelve explants per treatment were used and the bacterial overgrowth (expressed as percentage) after seven days of cultivation was calculated. The best treatment to eliminate bacteria was selected and its effect on the in vitro regeneration was assessed.

Assessment of kanamycin (Kn) as selective agent: The explants with a pre-cultivation time of seven days were cultured in RM supplemented with $0,25,50,100,200$ and $300 \mathrm{mg} / \mathrm{L}$ of kanamycin. Each treatment was replicated three times with seven explants per treatment. The explants were cultured at $25^{\circ} \mathrm{C}$ under a $16 \mathrm{hr}$ light $/ 8 \mathrm{hr}$ dark photoperiod. Sub-culture was performed every three weeks to the same medium. After three and six weeks of culture we recorded the survival rate, as well as the number of shoots and/or roots observed per explant.

Transient transformation experiments: The $A$. tumefaciens LBA4404-ElectroMAX ${ }^{\circledR}$ strain carrying the binary vector pCAMBIA1301 (11837 bp) was used. This vector contains the $\beta$-glucuronidase (gusA) reporter gene of Escherichia coli with an intron. The gusA gene under the $35 \mathrm{~S}$ promoter of the cauliflower mosaic virus (CaMV) and the poly(A) ending sequence contains the gene hpt (hygromycin phosphotransferase, a selective marker gene) controlled by the $35 \mathrm{~S}$ promoter and the poly (A) $35 \mathrm{~S}$ CaMV terminator.

Non-precultured EAs were incubated at room temperature in the bacterial suspension under 0.5 OD600nm. Later, bacterial excess was adsorbed with sterile filter paper and EAs were placed in Petri dishes containing RM. The effect of the co-culture period was assessed under three, four, and five days of incubation at $25{ }^{\circ} \mathrm{C}$ in the dark (Table 1). A second experiment assessed a pre-culture time of two days and a co-culture time of four days (Table 1).

Histochemical staining: After bacterial elimination, the gusA activity on EAs was detected by histochemical staining (Jefferson, Kavanagh, \& Bevan, 1987). Explants were incubated overnight at $37{ }^{\circ} \mathrm{C}$ in $100 \mathrm{mM}$ of phosphate sodium (NaH2PO4, $\mathrm{pH}$ 7.0) buffer containing $10 \mathrm{mM}$ EDTA, $0.5 \mathrm{mM}$ potassium ferrocyanide $\mathrm{K} 3 \mathrm{Fe}(\mathrm{CN} 6), 0.5 \mathrm{mM}$ potassium ferrocyanide $\mathrm{K} 3 \mathrm{Fe}(\mathrm{CN}) 6 \cdot 3 \mathrm{H} 2 \mathrm{O}$, and $0.2 \%$ Triton X-100. X-Gluc (5-bromo4-chloro-3-indolyl- $\beta$-D-glucuronide) dissolved in dimethyl sulfoxide (DMSO) under a final concentration of $0.7 \mathrm{mg} / \mathrm{L}$ was added to the solution. After incubation, the staining solution 
TABLE 1

Conditions of the genetic transformation of bean with LBA4404-ElectroMAX $₫$ of Agrobacterium

\begin{tabular}{|c|c|c|c|c|c|}
\hline Experiment & $\begin{array}{l}\text { Pre-cultivation } \\
\text { period (Days) }\end{array}$ & $\begin{array}{l}\text { Number of } \\
\text { explants }\end{array}$ & Plasmid & Infection & $\begin{array}{l}\text { Co-cultivation } \\
\text { period (Days) }\end{array}$ \\
\hline \multirow{3}{*}{1} & \multirow{3}{*}{0} & 11 & \multirow{3}{*}{ pCAMBIA1301 } & \multirow{3}{*}{ Immersion and agitation for $15 \mathrm{~min}}$. & 3 \\
\hline & & 11 & & & 4 \\
\hline & & 11 & & & 5 \\
\hline 2 & 2 & 197 & pCAMBIA1301 & Vacuum infiltration, $1 \mathrm{~h}, 1.25 \mathrm{plg} \mathrm{Hg}$ & 4 \\
\hline 3 & 12 & 30 & pCAMBIA1301 & Immersion and agitation for $15 \mathrm{~min}$ & 3 \\
\hline 4 & 2 & 405 & pBinRD29A-bifuncional & Vacuum infiltration, $1 \mathrm{~h}, 1.25 \mathrm{plg} \mathrm{Hg}$ & 4 \\
\hline 5 & 8 & 60 & pBinRD29A-bifuncional & Vacuum infiltration, $1 \mathrm{~h}, 1.25 \mathrm{plg} \mathrm{Hg}$ & 4 \\
\hline 6 & 10 & 120 & pBinRD29A-bifuncional & Vacuum infiltration, $1 \mathrm{~h}, 1.25 \mathrm{plg} \mathrm{Hg}$ & 4 \\
\hline 7 & 12 & 30 & pBinRD29A-bifuncional & Immersion and agitation for $15 \mathrm{~min}$ & 3 \\
\hline 8 & 17 & 45 & pBinRD29A-bifuncional & Vacuum infiltration, $1 \mathrm{~h}, 1.25 \mathrm{plg} \mathrm{Hg}$ & 4 \\
\hline
\end{tabular}

was removed and EAs were put in ethanol (70 $\%$ ) for $24 \mathrm{~h}$ to eliminate chlorophylls. The presence of blue points was identified by means of a stereomicroscope (LEICA E24HD) and was registered and interpreted as transient expression of gusA. Photographs were taken with the digital camera of the stereomicroscope (LEICA E24HD). The transient expression of gus A was measured by counting the number of explants with at least one blue foci. The frequency of transient expression of GUS was calculated as the number of explants with at least one blue foci over the total number of explants (expressed as percentage).

Stable transformation: To assess the stability of the transformation binary and bifunctional vector $\mathrm{pBindrd29A}$ was used. This vector contains the selective marker nptII, which provides resistance to kanamycin and a fusion of genes containing regions of trehalose-6-phosphate synthase (tps 1) and trehalose-6-phosphatase synthase (tps2) from Saccharomyces cerevisiae (Miranda et al., 2007) under the stress inducible promoter rd29A of Arabidopsis thaliana (Yamaguchi-Shinozaki \& Shinozaki, 1994). This vector was added to the Agrobacterium tumefaciens LBA4404-ElectroMAX ${ }^{\circledR}$ strain. The vector and the fusion of the bifunctional genes (rd29A::tps-tpp) had a size of 16.02 and $2.9 \mathrm{~kb}$, respectively (Santamaría et al., 2009). Bacterial preparation was performed as indicated previously. Transformation of common bean was carried out during two, eight, ten, 12, and 17 days of precultivation, and three and four days co-culture (Table 1).

After the co-cultivation period, bacteria were eliminated with the selected treatment of previous experiments. Explants were then cultured to RM added with $500 \mathrm{mg} / \mathrm{L}$ of timentin and $50 \mathrm{mg} / \mathrm{L}$ of kanamycin under the conditions previously described. Sub-cultures were made every three - four weeks for more than 120 days. The number of shoots surviving the selection process since the first sub-culture, was recorded. The transformation frequency of the selective gene was calculated as the number of kanamycin-resistant explants over the total number of explants.

PCR amplification of nptII and TPS1 genes: Genomic DNA was isolated from leaf tissues from four-five month old regenerated bean plants according to the extraction kit protocol MACHERY-NAGEL.

The extraction of DNA from pBindrd29A was performed according to the manual for plasmid purification (INVITROGEN). The primers used for PCR amplification correspond to the TPS1 sequence forward (5' GTGGCAGAGGAGCTTGTTGAG 3'), and reverse (5' GGTACTCACATACAGAC 3'), which amplify a fragment of approximately $1600 \mathrm{bp}$. The final composition of the reaction mixture 
was: $2.5 \mu \mathrm{l}$ buffer $10 \mathrm{X}, 1.0 \mu \mathrm{L}$ Nucleotide Mix 10mM, $2 \mu \mathrm{l} \mathrm{MgCl} 250 \mathrm{mM}, 1 \mu \mathrm{L}$ Forward primer (stock $10 \mathrm{picomol} / \mu \mathrm{l}$ ) and $1 \mu \mathrm{L}$ reverse primer (stock $10 \mathrm{picomol} / \mu \mathrm{L}$ ), $1 \mu \mathrm{l}$ plasmid DNA and $0.2 \mu \mathrm{l}$ taq. The reaction conditions were: $94{ }^{\circ} \mathrm{C}$ for $5 \mathrm{~min}(1 \mathrm{x}), 30$ amplification cycles $\left(94{ }^{\circ} \mathrm{C}\right.$ for $1 \mathrm{~min}, 50{ }^{\circ} \mathrm{C}$ for $1 \mathrm{~min}, 72^{\circ} \mathrm{C}$ for $2 \mathrm{~min}$ ), and a final extension step at $72^{\circ} \mathrm{C}$ for $10 \mathrm{~min}$.

The primers for the nptII gene were: forward 5'-GAGGCTATTCGGCTATGACTG and reverse 5'-TCGACAAGACCGGCTTCCATC (Aragão et al., 1996), which amplify a $410 \mathrm{bp}$ fragment. The final composition of the reaction mixture was: $10 \mu \mathrm{l}$ Master Mix $10 \mathrm{mM}$, $0.25 \mu \mathrm{l}$ forward primer (stock $10 \mu \mathrm{M} / \mu \mathrm{l}$ ) and $0.25 \mu 1$ reverse primer (stock $10 \mathrm{picomol} / \mu \mathrm{l}$ ), $1 \mu 1$ DNA (1:10). The reaction conditions were $94{ }^{\circ} \mathrm{C}$ for $5 \mathrm{~min}(1 \mathrm{x}), 35$ amplification cycles ( 35 cycles of $94{ }^{\circ} \mathrm{C}$ for $30 \mathrm{~s}, 58^{\circ} \mathrm{C}$ for $30 \mathrm{~s}$ and $72{ }^{\circ} \mathrm{C}$ for $1 \mathrm{~min}$ ) and a final step at $72{ }^{\circ} \mathrm{C}$ for 5 min and $4{ }^{\circ} \mathrm{C}$.

PCR products were separated by electrophoresis on $1 \%(\mathrm{w} / \mathrm{v})$ agarose gels under 100 $\mathrm{V}$ for $50 \mathrm{~min}$ and stained with Loading Dye 6X (added with $0.6 \%$ of Gel Red) (8 $\mu$ l of PCR product was mixed with $2 \mu$ of Loading Dye 6X $2 \mu \mathrm{l}$ molecular marker weight, $2 \mu \mathrm{l}$ Gel Red. Gene Ruler 1 Kb Plus DNA Ladder, ready to use).

Presence of $A$. tumefaciens in transformed plants: The amplification by PCR of VirE2 gene fragment of A. tumefaciens was examined using the primers: forward
(5'-TGCCCACCAAGGCGGAATT-3') and reverse (5'-CTTTGCCGACCCATCGA-3') which amplifies a fragment of $895 \mathrm{bp}$. The volume of the reaction mixture was of $25 \mathrm{ml}$ containing $2.5 \mu \mathrm{l}$ buffer $10 \mathrm{X}, 50 \mathrm{mM} \mathrm{MgCl} 2$, $10 \mathrm{mM}$ dNTPS, $0.1 \mu \mathrm{l}$ Taq polimerase, $1 \mu \mathrm{l}$ sense primer, $1 \mu 1$ antisense primer and $1 \mu \mathrm{l}$ plant DNA. The reaction conditions were 94 ${ }^{\circ} \mathrm{C}$ for 30 seconds, 30 cycles of temperature of denaturing $94^{\circ} \mathrm{C}$ for $5 \mathrm{~min}$, primer annealing $55^{\circ} \mathrm{C}$ for $5 \mathrm{~min}$, elongation $72^{\circ} \mathrm{C}$ for $2 \mathrm{~min}$ and $72{ }^{\circ} \mathrm{C}$ for $10 \mathrm{~min}$ and $4{ }^{\circ} \mathrm{C}(10 \mathrm{~min})$. The amplified fragments were separed in $1 \%(\mathrm{w} / \mathrm{v})$ agarose gel to $100 \mathrm{~V}$ by $40 \mathrm{~min}$.

All the experiments were undertaken under completely randomized designs and the statistical analysis was performed using one-way ANOVA. Means (shoots per explants, height of shoots, roots per regenerants and lenght of roots) were separated by the Duncan's test at $\mathrm{P}$ $<0.05$. The program SPSS Statistics version 23 was used (IBM Corp., 2015).

\section{RESULTS}

A. tumefaciens elimination after the coculture: Pre-cultured and co-cultured explants with LBA4404-ElectroMAX ${ }^{\circledR}$ Agrobacterium showed a $100 \%$ bacterial suppression regardless the concentrations of cefotaxime and timentin. However, the same antibiotics treatments did not completely eliminate bacteria in non-pre-cultured explants (Table 2).

For the elimination of $A$. tumefaciens the most efficient and compatible with further

TABLE 2

Recidivism of LBA4404-ElectroMAX ${ }^{\circledR}$ A. tumefaciens in explants of $P$. vulgaris $\mathrm{L}$. with or without pre-cultural times and co-cultivated during four days

\begin{tabular}{|c|c|c|}
\hline \multirow{2}{*}{ Treatments } & \multicolumn{2}{|c|}{$\%$ of Bacterial Recidivism } \\
\hline & Without pre-culture & With pre-culture \\
\hline Control (with neither co-culture nor antibiotics) & 0 & 0 \\
\hline Control (with co-culture and RM without antibiotics) & 92 & 100 \\
\hline $\mathrm{RM}+500 \mathrm{mg} / \mathrm{L}$ timentin $+500 \mathrm{mg} / \mathrm{L}$ cefotaxime & 67 & 0 \\
\hline $\mathrm{RM}+500 \mathrm{mg} / \mathrm{L}$ timentin & 92 & 0 \\
\hline $\mathrm{RM}+750 \mathrm{mg} / \mathrm{L}$ timentin & 92 & 0 \\
\hline
\end{tabular}

Observations were taken after six days of starting the treatment. 
development was the use of $500 \mathrm{mg} / \mathrm{L}$ timentin and also in the RM did not affect the in vitro response of the common bean (data not shown).

\section{Assessment of the kanamycin as selec-} tive agent: Among the assessed Kn concentrations, $25 \mathrm{mg} / \mathrm{L}$ was the only concentration that did not caused complete mortality of the explants after six weeks in culture, while concentrations of around (or higher than) $50 \mathrm{mg} / \mathrm{L}$ reached a $100 \%$ mortality. Hence, the following experiments used a minimum lethal dose of $50 \mathrm{mg} / \mathrm{L} \mathrm{Kn}$ to select the bean cells which were possibly transformed by the nptII gene.

\section{Transient transformation experi-} ments: Non-pre-cultured EAs inoculated with 0.5 OD600nm and co-cultured for three and five days showed $\beta$-glucuronidase activity in $45 \%$ and $1.4 \%$ of total explants, respectively
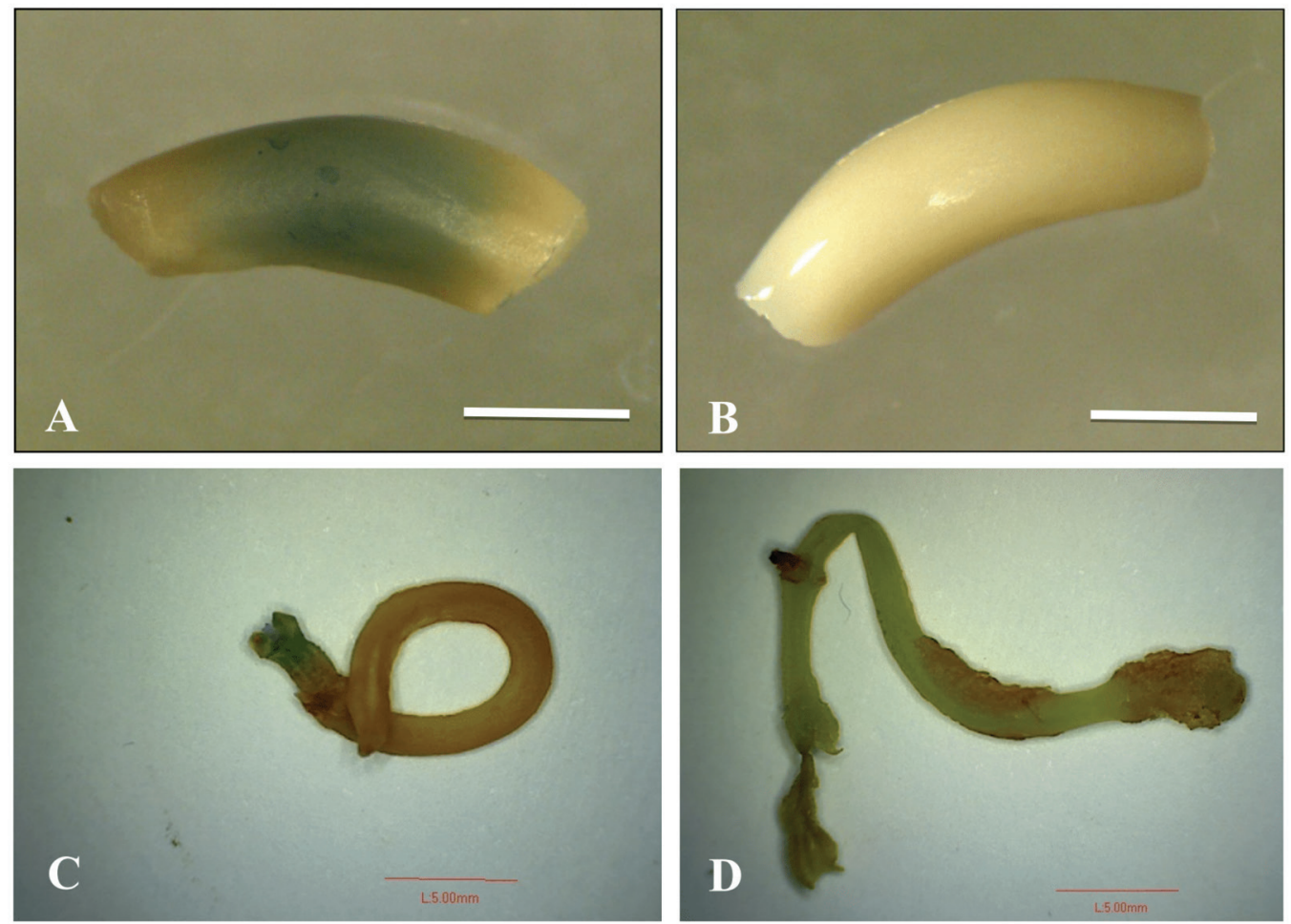

(Fig. 1A). In the case of EAs co-cultured for four days, no $\beta$-glucuronidase activity was detected. Only $0.5 \%$ of the explants precultured for two days and co-cultured for four days showed gusA activity (Fig. $1 \mathrm{C}$ ). Furthermore, non-co-cultured explants showed an absence of endogenous GUS activity (Fig. 1B and Fig. 1D).

Stable genetic transformation: Regenerants from $50 \mathrm{mg} / \mathrm{L}$ kanamycin treatment, were obtained from explants co-cultured with pBindrd29A (Table 1). These regenerants were selected 120 days after the first sub-culture (Table 3). A higher number of regenerants in the presence of the selective medium was observed in those cases under a long-term pre-culture (equal or higher than eight days). Regenerants from explants pre-cultured for 12 days and co-cultured for three days showed a

Fig. 1. GusA activity in P. vulgaris L. explants co-cultivated with A. tumefaciens LBA4404 pCAMBIA1301 with 0.5 OD600nm. A and B: non pre-cultured. C and D: pre-cultured for two days. A. co-cultivated EA for five days and B. noninfected EA (negative control), C. co-cultivated EA for four days and D. non-infected EA. Scale bars A and B= $2 \mathrm{~mm}, \mathrm{C}$ and $\mathrm{D}=5 \mathrm{~mm}$. 
higher survival rate (Table 3). Explants with a short-term pre-culture (two days) showed a low transformation frequency for the selective agent (Table 3). Fig. 2A indicates the presence of A. tumefaciens cells. In contrast, kanamycinbased selected plants did not show this amplification and the presence of the nptII gene was detected (Fig. 2B).

PCR assessment of possible transformation: Plants pre-cultured and co-cultured for two and four days respectively, showed an amplification fragment of a $410 \mathrm{bp}$ which corresponded to the expected size for the selective gene (Fig. 2A). Kanamycin-based selected plants did not show this amplification. Regenerants with kanamycin resistance were assessed by PCR to determine the presence of the nptII gene (Fig. 2 B). These results indicate a transformation efficiency of $0.5 \%$ for the $n p t I I$ gene in plants of common bean.

\section{DISCUSSION}

The main limitation/constrain for obtaining transformed bean plants is the lack of an adequate genetic transformation system due to recalcitrance to the in vitro regeneration and the low Agrobacterium-mediated transformation rates.

Bacteria elimination after co-culture was also very difficult as the only way to genetically transform beans by the time this work started was by biolistics (Faria et al., 2006). Results indicated that $500 \mathrm{mg} / \mathrm{L}$ timentin eliminated the LBA4404 ElectroMax strain of Agrobacterium tumefaciens after the co-culture, which is in accordance to recent reports (Mukeshimana, Ma, Walworth, Song, \& Kelly, 2013).

Bean EAs co-cultured for three days under 0.5 OD600nm and incubated at $25{ }^{\circ} \mathrm{C}$ showed $\beta$-glucuronidase activity. This suggests a transient transformation of $45 \%$, which is similar to that recently reported by Collado et al. (2016), (46\%) using the C58C1RifR strain and a higher co-culture time (five days). This transformation efficiency increased $(80 \%)$ with the EHA101 strain under the same conditions

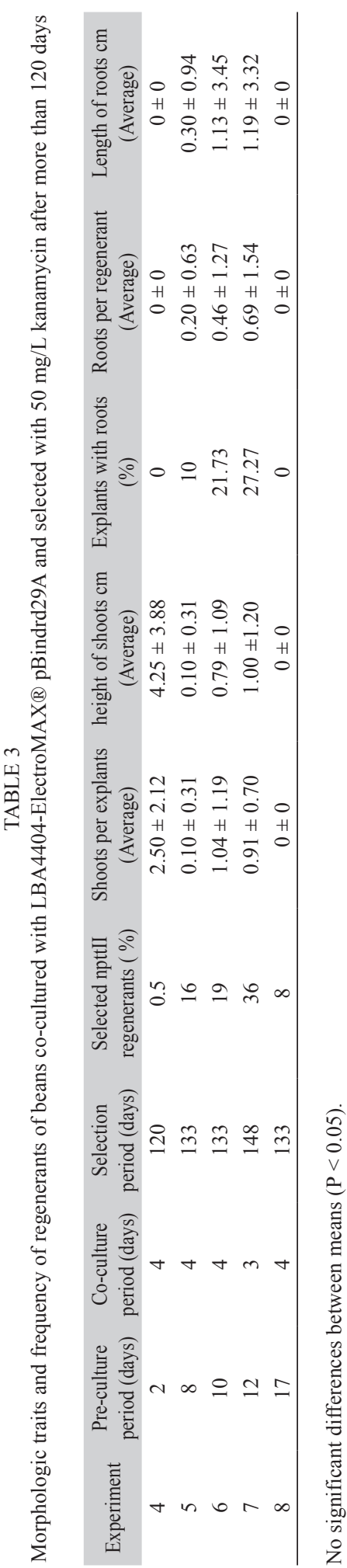




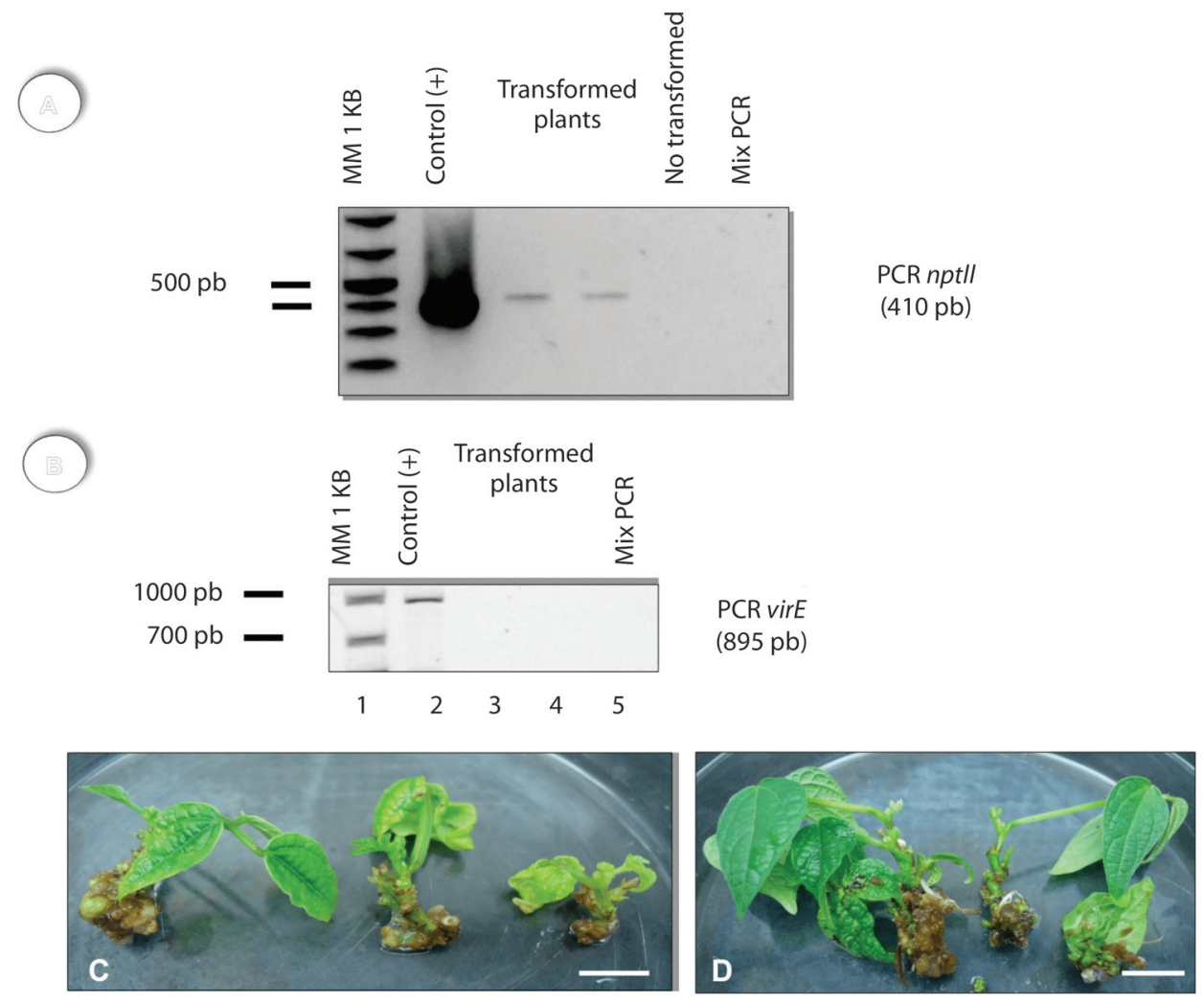

Fig. 2. Plants or common bean transformed with the $n p t I I$ gene (120 days of culture). A. Amplification of a 410 bp fragment corresponding to the expected size of the selective gene. B. Absence fragment virE in transformed tissues, line 1: DNA ladder (1 Kb), line 2: Agrobacterium, Lines 3-4: regenerated and selected plants (third experiment) and line 5: load control. C. Regenerated and kanamycin-resistant plants. D. Non-transformed plants. Scale C and D bars $=1 \mathrm{~cm}$.

(Collado et al., 2016). These results evidence the lack of endogenous gusA activity in the assessed bean explants. However, this is not the case for other species (Solís-Ramos, GonzálezEstrada, Andrade-Torres, Godoy-Hernández, \& Castaño de la Serna, 2010). The gusA reporter gene is useful for experiments related to the transformation of certain species and is suitable for histochemical staining and localization of transformed cells.

In this work, the regeneration or "shoots proliferation" from EAs was consistent with previous reports that concluded this type of explant is regenerable but not optimum for the Agrobacterium-mediated genetic transformation and subsequent shoots production (Delgado-Sánchez et al., 2006; Arellano, Fuentes, Castillo-España, \& Hernández, 2009;
Quintero-Jiménez, Espinosa-Huerta, AcostaGallegos, Guzmán-Maldonado, \& Mora-Avilés, 2010; Mukeshimana et al., 2013; Solís-Ramos et al., 2015).

Optimum bacteria concentration is a relevant parameter for a transformation protocol (Collado et al., 2015). An OD600nm lower than 0.5 will not allow for genetic transformation and higher concentrations kill the explants. According to previous results (data not shown), the bacteria (LBA4404-ElectroMAX®) were used at an OD600nm of 0.5. Previous reports used similar conditions (Mukeshimana et al., 2013; Collado et al., 2015, 2016).

The OD600nm was combined with shortterm co-cultures (three - four days). Three-days co-cultures favored the insertion of the marker gene (GUS or nptII), which agrees with the 
results reported by (Amugune et al., 2011). On the other hand, previous studies indicate long-term co-cultures of five days (Collado et al., 2016), six days (Collado et al., 2015), and eight days (Espinosa-Huerta et al., 2013; Mukeshimana et al., 2013) increase the temporary expression of the transgene (Zambre et al., 2003; Mukeshimana et al., 2013) especially in embryonic axes (Mukeshimana et al., 2013). The presence of BAP in the co-culture and regeneration media favored transformation and survival of the explants. Other studies report similar results (Zhang et al., 1997; Amugune et al., 2011).

Unlike other species, bean did not show natural resistance to kanamycin (Solís-Ramos et al., 2009) as $50 \mathrm{mg} / \mathrm{L}$ allowed for selecting the bean regenerants for a four -month time period. In this study, the selection was applied after the first sub-culture (four weeks) to allow transformed cells to proliferate and develop a group of cells capable to survive in middle of a mass of death cells derived from a lethal dose of antibiotic (Zambre et al., 2005). According to Amugune et al. (2011), it should be possible to recover Agrobacterium-transformed plants after bean explants had been exposed to the selection medium during three to four weeks (one month). Among all the shoots selected during more than 120 days, only four of them showed an amplification corresponding to the expected size of the ntpII gene. These results evidence that the type of the explant (embryonic axes) used in the experiment is not suitable for the regeneration of transformed plants (Mukeshimana et al., 2013), as the obtained shoots are from multicellular origin, which may inhibit the strict selection of transgenic shoots, and allows a high number of "leaks" (nontransgenic plants that survive the selection) and chimeras (Angenon \& Thu, 2011). Therefore, an important contribution to enhance bean is the establishment of a regeneration system via somatic embryogenesis, or a regeneration system derived from the meristem-free tissue that minimize the production of chimeric transformants (Mukeshimana et al., 2013).
In this study, the transformation frequency obtained for the reporter and selective gene was $0.5 \%$, which is slightly higher to that reported for the species using biolistic $0.3 \%$ (Aragão et al., 1996; Faria et al., 2006; Rech et al., 2008). Recently, higher transformation efficiencies (2.8 and $0.75 \%)$ have been reported using hypervirulent strains of $A$. tumefaciens (EHA105 or EHA101). This affects the transfer capacity of T-DNA as chromosomal and virulence genes may differ from one strain to another (Collado et al., 2015, 2016). In the case of the TPS1 gene, the fragment was amplified in transformed explants and the controls explants, and it was not possible make a conclusion on this gene.

So far, few studies report the Agrobacterium-assisted genetic transformation for bean and no plants have been obtained, due to the lack of a regeneration protocol (Angenon \& Thu, 2011; Mukeshimana et al., 2013). However, Collado et al. $(2015,2016)$ could recently transform beans with genetic markers (bar, nptII y uidA) producing chimeric regenerants through direct and indirect organogenesis from epicotyl. However, the established protocol did not rendered stable genetic transformation (Collado et al., 2016).

In this study, explants of common bean cocultivated with LBA4404-ElectroMAX ${ }^{\circledR}$ from A. tumefaciens, were obtained. These showed $\beta$-glucuronidase activity indicating a temporary genetic transformation (gusA gene) of $45 \%$ efficiency. Bean regenerants with kanamycin were selected during three to five weeks for stable transformation. However, this selection was not strict because the regenerants from multicellular origin generated chimeric transformants, leading to leaks of non-transgenic materials. Stable transformation for the nptII gene was obtained at $0.5 \%$ efficiency, which agrees with the results related to the temporary transformation for gusA using the same protocol. The established protocol for genetic transformation of common bean has two additional advantages with respect to previous reports: (1) it allows for obtaining transformed regenerants 
and (2) the genetic transformation was stable for the selective gene.

Ethical statement: authors declare that they all agree with this publication and made significant contributions; that there is no conflict of interest of any kind; and that we followed all pertinent ethical and legal procedures and requirements. All financial sources are fully and clearly stated in the acknowledgements section. A signed document has been filed in the journal archives.

\section{ACKNOWLEDGEMENTS}

Thanks to the Fabio Bautrit Moreno Agricultural Experimental Station (EEAFBM-UCR) and Juan Carlos Hernández (UCR-PITTA bean) for providing the variety of common bean used in this research. Also, thanks to Norman Rojas (Escuela de Microbiologia, UCR) for providing the Escherichia coli (HB101) strain, Wilma González Kantún (Bioquímica y Biología Molecular de Plantas, CICY, Mérida, Yucatán) and Bruce Williamson Benavides for the technical support, Carolina Céspedes Garro and Andrea Ramírez Telles (Escuela de Biología, UCR) for repeating the molecular assessments of the potential regenerated and selected transformants, and to the DAAD for additional funding. Finally, thanks to the ViceRectory of Research (Universidad de Costa Rica), for research funding (project No. 111B2-052). To the CICY (Centro de Investigación Científica de Yucatán) for the vectors donated for this research.

\section{RESUMEN}

Transformación de frijol común (Phaseolus vulgaris) var. Brunca mediada por Agrobacterium tumefaciens. El frijol común en un cultivo recalcitrante a la regeneración in vitro y se carece de un protocolo eficiente y reproducible de transformación genética usando A. tumefaciens. Desarrollamos un protocolo de transformación genética mediada por $A$. tumefaciens de frijol común variedad Brunca utilizando genes marcadores (gusA y nptII) junto con el gen de la trehalosa-6-fosfato sintasa de levadura (TPS1) utilizado para incrementar tolerancia a estrés abiótico. La actividad de la $\beta$-glucoronidasa fue detectada en $45 \%$ de los explantes infectados con la cepa LBA4404 de A. tumefaciens transformada con pCAMBIA1301. Después de 4 o 5 meses se regeneraron tallos en un medio adicionado con kanamicina. Los explantes supervivientes se evaluaron mediante PCR y presentaron una eficiencia de transformación de $0.5 \%$. El protocolo de transformación genética de frijol común establecido tiene dos ventajas adicionales con respecto a los reportes previos: (1) permite la obtención de regenerares transformados y (2) la transformación genética fue estable para el gen selectivo.

Palabras clave: frijol común; especies recalcitrantes; transformación genética; A. tumefaciens; actividad gusA; nptII.

\section{REFERENCES}

Amugune, N. O., Anyango, B., \& Mukiama, T. K. (2011). Agrobacterium-mediated transformation of common bean. African Crop Science Journal, 19(3), 137-147.

Angenon, G., \& Thu, T.T. (2011). Genetic transformation. In A. Pratap \& J. Kumar (Eds.), Biology and Breeding of Food Legumes (pp. 178-192). USA: CABI.

Aragão, F. J. L., Barros, L. M. G., Brasileiro, A. C. M., Ribeiro, S. G., Smith, F. D., Sanford, J. C., Rech, E. L. (1996). Inheritance of foreign genes in transgenic bean (Phaseolus vulgaris L.) co-transformed via particle bombardment. Theoretical and Applied Genetics, 93(1-2), 142-150. DOI: 10.1007/BF00225739

Aragão, F., \& Faria, J. (2009). First transgenic geminivirusresistant plant in the field. Nature Biotechnology, 27, 1086-1088. DOI:10.1038/nbt1209-1086

Aragão, F. J. L., Nogueira, E. O. P. L., Tinoco, M. L. P., \& Faria, J. C. (2013). Molecular characterization of the first commercial transgenic common bean immune to the Bean golden mosaic virus. Journal of Biotechnology, 166(1), 42-50. DOI: 10.1016/j. jbiotec.2013.04.009

Aragão, F. J. L., Vianna, G. R., Albino, M. M. C., \& Rech, E. L. (2002). Transgenic Dry Bean Tolerant to the Herbicide Glufosinate Ammonium. Crop Science, 42(4), 1298. DOI: $10.2135 /$ cropsci2002.1298

Arellano, J., Fuentes, S. I., Castillo-España, P., \& Hernández, G. (2009). Regeneration of different cultivars of common bean (Phaseolus vulgaris L.) via indirect organogenesis. Plant Cell, Tissue and Organ Culture, 96(1), 11-18. DOI: 10.1007/s11240-008-9454-1

Bonfim, K., Faria, J. C., Nogueira, E. O. P. L., Mendes, É. A., \& Aragão, F. J. L. (2007). RNAi-Mediated Resistance to Bean golden mosaic virus in Genetically Engineered Common Bean (Phaseolus vulgaris). Molecular Plant-Microbe Interactions, 20(6), 717726. DOI: 10.1094/MPMI-20-6-0717 
Collado, R., Bermúdez-Caraballoso, I., García, L. R., Veitía, N., Torres, D., Romero, C., \& Angenon, G. (2016). Epicotyl sections as targets for plant regeneration and transient transformation of common bean using Agrobacterium tumefaciens. In Vitro Cellular \& Developmental Biology - Plant, 52(5), 500-511. DOI: 10.1007/s11627-016-9769-2

Collado, R., Bermúdez-Caraballoso, I., García, L. R., Veitía, N., Torres, D., Romero, C., Angenon, G. (2015). Agrobacterium-mediated transformation of Phaseolus vulgaris L. using indirect organogenesis. Scientia Horticulturae, 195 (Supplement C), 89-100. DOI: 10.1016/j.scienta.2015.06.046

Delgado-Sánchez, P., Saucedo-Ruiz, M., GuzmánMaldonado, S. H., Villordo-Pineda, E., GonzálezChavira, M., Fraire-Velázquez, S., ... Mora-Avilés, A. (2006). An organogenic plant regeneration system for common bean (Phaseolus vulgaris L.). Plant Science, 170(4), 822-827. DOI: 10.1016/j. plantsci.2005.11.015

Espinosa-Huerta, E., Quintero-Jiménez, A., Cabrera-Becerra, K. V., \& Mora-Avilés, M. A. (2013). Stable and efficient Agrobacterium tumefaciens mediated transformation of Phaseolus vulgaris. Agrociencia, 47(4). Retrieved from http://www.redalyc.org/resumen.oa?id=30226975002

Faria, J. C., Albino, M. M. C., Dias, B. B. A., Cançado, L. J., da Cunha, N. B., de M. Silva, L., ... Aragão, F. J. L. (2006). Partial resistance to Bean golden mosaic virus in a transgenic common bean (Phaseolus vulgaris L.) line expressing a mutated rep gene. Plant Science, 171(5), 565-571. DOI: 10.1016/j. plantsci.2006.06.010

Franklin, C. I., Trieu, T. N., Cassidy, B. G., Dixon, R. A., \& Nelson, R. S. (1993). Genetic transformation of green bean callus via Agrobacterium mediated DNA transfer. Plant Cell Reports, 12(2), 74-79. DOI: 10.1007/ BF00241938

Gepts, P., Aragão, F. J. L., De Barros, E., Blair, M. W., Brondani, R., Broughton, W., Yu, K. (2008). Genomics of Phaseolus Beans, a Major Source of Dietary Protein and Micronutrients in the Tropics. In P. H. Moore, \& R. Ming (Eds.), Genomics of Tropical Crop Plants (pp. 113-143). New York: Springer. DOI: 10.1007/978-0-387-71219-2_5

IBM Corp. (2015). IBM SPSS Statistics for Windows (Version 23.0). Armonk, NY: IBM Corp.

Jefferson, R. A., Kavanagh, T. A., \& Bevan, M. W. (1987). GUS fusions: beta-glucuronidase as a sensitive and versatile gene fusion marker in higher plants. The EMBO Journal, 6(13), 3901-3907.

Liu, Z., Park, B.-J., Kanno, A., \& Kameya, T. (2005). The Novel Use of a Combination of Sonication and Vacuum Infiltration in Agrobacterium-mediated Transformation of Kidney Bean (Phaseolus vulgaris
L.) with lea Gene. Molecular Breeding, 16(3), 189. DOI: $10.1007 / \mathrm{s} 11032-005-6616-2$

Miranda, J. A., Avonce, N., Suárez, R., Thevelein, J. M., Dijck, P. V., \& Iturriaga, G. (2007). A bifunctional TPS-TPP enzyme from yeast confers tolerance to multiple and extreme abiotic-stress conditions in transgenic Arabidopsis. Planta, 226(6), 1411-1421. DOI: $10.1007 / \mathrm{s} 00425-007-0579-y$

Mukeshimana, G., Ma, Y., Walworth, A. E., Song, G., \& Kelly, J. D. (2013). Factors influencing regeneration and Agrobacterium tumefaciens-mediated transformation of common bean (Phaseolus vulgaris L.). Plant Biotechnology Reports, 7(1), 59-70. DOI: 10.1007/s11816-012-0237-0

Murashige, T., \& Skoog, F. (1962). A Revised Medium for Rapid Growth and Bio Assays with Tobacco Tissue Cultures. Physiologia Plantarum, 15(3), 473-497. DOI: 10.1111/j.1399-3054.1962.tb08052.x

Quintero-Jiménez, A., Espinosa-Huerta, E., Acosta-Gallegos, J. A., Guzmán-Maldonado, H. S., \& Mora-Avilés, M. A. (2010). Enhanced shoot organogenesis and regeneration in the common bean (Phaseolus vulgaris L.). Plant Cell, Tissue and Organ Culture (PCTOC), 102(3), 381-386. DOI: 10.1007/s11240-010-9744-2

Rech, E. L., Vianna, G. R., \& Aragão, F. J. (2008). Highefficiency transformation by biolistics of soybean, common bean and cotton transgenic plants. Nature Protocols, 3(3), 410.

Russell, D. R., Wallace, K. M., Bathe, J. H., Martinell, B. J., \& McCabe, D. E. (1993). Stable transformation of Phaseolus vulgaris via electric-discharge mediated particle acceleration. Plant Cell Reports, 12(3), 165169. DOI: $10.1007 / \mathrm{BF} 00239099$

Santamaría, J. M., Hernández-Portilla, D., Chi-Manzanero, B., Espadas, F., Castaño, E., Iturriaga, G., \& Rodríguez-Zapata, L. C. (2009). Incorporation of two trehalose biosynthetic genes in banana increases trehalose levels and protects the photosynthetic apparatus from salt-stress damage. The Journal of Horticultural Science and Biotechnology, 84(6), 665-671. DOI: $10.1080 / 14620316.2009 .11512583$

Solís-Ramos, L. Y., González-Estrada, T., Andrade-Torres, A., Godoy-Hernández, G., \& Castaño de la Serna, E. (2010). Endogenous GUS-like activity in Capsicum chinense Jacq. Electronic Journal of Biotechnology, 13(4), 2-3.

Solís-Ramos, L. Y., González-Estrada, T., Nahuath-Dzib, S., Zapata-Rodriguez, L. C., \& Castaño, E. (2009). Overexpression of WUSCHEL in C. chinense causes ectopic morphogenesis. Plant Cell, Tissue and Organ Culture (PCTOC), 96(3), 279-287. DOI: 10.1007/ s11240-008-9485-7

Solís-Ramos, L. Y., Valdez, M., Alvarado-Barrantes, R., Mora-Umaña, F., Hernández, E., Barboza, N., \& 
Ramírez-Fonseca, P. (2015). Effect of Gamma Irradiation and Selection with Fungus Filtrate (Rhizoctonia solani Kuhn) on the in vitro Culture of Common Bean (Phaseolus vulgaris). American Journal of Plant Science, 6, 2672-2685. DOI: 10.4236/ ajps.2015.616269

Vianna, G. R., Albino, M. M. C., Dias, B. B. A., de Mesquita Silva, L., Rech, E. L., \& Aragão, F. J. L. (2004). Fragment DNA as vector for genetic transformation of bean (Phaseolus vulgaris L.). Scientia Horticulturae, 99(3), 371-378. DOI: 10.1016/ S0304-4238(03)00107-9

Yamaguchi-Shinozaki, K., \& Shinozaki, K. (1994). A novel cis-acting element in an Arabidopsis gene is involved in responsiveness to drought, low-temperature, or high-salt stress. The Plant Cell, 6(2), 251-264.
Zambre, M., Goossens, A., Cardona, C., Montagu, M. V., Terryn, N., \& Angenon, G. (2005). A reproducible genetic transformation system for cultivated $\mathrm{Pha}$ seolus acutifolius (tepary bean) and its use to assess the role of arcelins in resistance to the Mexican bean weevil. Theoretical and Applied Genetics, 110(5), 914-924. DOI: 10.1007/s00122-004-1910-7

Zambre, M., Terryn, N., Clercq, J. D., Buck, S. D., Dillen, W., Montagu, M. V., Angenon, G. (2003). Light strongly promotes gene transfer from Agrobacterium tumefaciens to plant cells. Planta, 216(4), 580-586. DOI: 10.1007/s00425-002-0914-2

Zhang, Z., Coyne, D. P., \& Mitra, A. (1997). Factors Affecting Agrobacterium-mediated Transformation of Common Bean. Journal of the American Society for Horticultural Science, 122(3), 300-305. 